Volume 5 Issue 2, June 2018

\title{
Legal Protection For Debtors In Selling Of Immovable Guaranteed Objects Below The Market Price In Indonesian Positive Law
}

\author{
Djatmika Malik ${ }^{1}$, Mangirim Limbong ${ }^{2}$ and Sri Endah Wahyuningsih ${ }^{3}$
}

\begin{abstract}
The difference price that occurs, in the implementation of execution of the debtor's collateral object, the creditor should pay attention on the debtor's right, ie the debtor should get a normal price on the guaranteed good which is being executed. It is related to the debtor's obligation, in case that the object's price is under the value of the debt. The issues raised in this study are how the process of selling immovable goods under the positive law in Indonesia, How the actions that can be done by the debtor if the guaranty is sold by the creditor below the market price, How legal protection for the debtor in selling the immovable goods under the provisions of Indonesia's positive law. The research method used was normative juridical research with approach of law, concept, and case study. The results of this study found that, first, the initial procedure in selling the immovable goods is through an auction request. The auction request is made by the seller, in this case the creditor. Second, if the sale is conducted through auction, it can be requested for loss of a lawsuit against the law only found any mistake in the implementation of auction procedures. And third, these aspects include: Debtor position related to the determination of the limit value, the position of the debtor in the event of auction cancellation; The position of the debtor in the case of the sale of a guaranteed underhand object; and the position of the debtor when the item has been sold and is in a third party.

Keywords: Protection; Sale; Positive Law; Immovable Objects.
\end{abstract}

\section{Introduction}

Debt is (1) Liability on a claim; a specific sum of money due to agreement or otherwise, (2) The aggregate of all existing claims against a person, entity, or state; (3) A nonmonetary thing that one person owes another, such as goods or services; (4) A common-law writ by which a court adjudicates claims involving fixed sums of money. ${ }^{4}$ Debts can arise because of two things, due to engagement or due to something else. One example of the emergence of debt due to other things is the tax debt arising from taxpayer liability, or debt arising due to the judge's verdict. Debts can arise not only because the debtor obtains a loan in the form of money from the creditor, but it can also arise because a person obtains an item or service from someone else eg a person who gets parking services has a debt of parking fees charged to the local government along with the parking attendant.

Debt can be divided into two, namely long-term debt and short-term debt. Long term debt is a debt that matures more than a year and the source of payment is not from current assets, while short-term debt is debt that will be repaid within one year or one company cycle. Debt is the fastest mean in any way for companies and individuals to get fresh funds that can be used to grow a business. However, due diligence in the use of debt may cause a person or corporation to become a bankrupt which may further be dropped.

\footnotetext{
${ }^{1}$ Student of Master Program (S2) of Notaries Faculty of Law Universitas Islam Sultan Agung email malikdyatmika8@gmail.com

2 Students of Master of Law, Faculty of Law, Universitas Islam Sultan Agung email limbongmangirim@yahoo.co.id

${ }^{3}$ Lecturer of Faculty of Law UNISSULA

${ }^{4}$ Bryan A. Garner ed 2009 Black's Law Dictionary Ninth Edition West St. Paul p. 462.
} 
Deviations due to pledge and mortgage are deviations that occur because of the agreement. Thus, it is clear that the receivables whose payments should take precedence are called preference receivables or special receivables, whereas settled receivables are settled according to the principle of equilibrium called konkruen receivables. The function of the guarantee is to convince the bank or creditor that the debtor has the ability to repay or repay the credits granted to him in accordance with agreed terms and credit agreements. ${ }^{5}$

Article 499 of the Civil Code provides an understanding of the object that determines, "According to the law, material object is every goods and every right, which can be controlled by property rights". The provision clearly indicates that what is meant by the object is everything that can be mastered by the subject of law with the property right, whether in the form of tangible object or intangible object that is right. ${ }^{6}$

Most of the guaranteed objects will decrease in value as time goes on. Such collateral goods are primarily concerned with security objects that are closely related to the technology. Like the car for example, the longer its value will be reduced due to the presence of new cars with new technology as well. Reduced value may cause harm to the creditors holding the guarantee rights. Therefore, in order to reduce the losses, the lender may determine that the value of the collateral is below the market price.

However, not all collateral goods are decreasing in value, antiques objects and land for example. Both objects are increasingly the value by the days. Judging from the above statement, it can be concluded that the value of the object of the collateral item affixed in the deed of guarantee is sometimes not in accordance with the market price at the time the debtor made a default. Such discrepancies may result in a loss to the debtor, especially if the minimum value of the auctioned item follows the price on the deed and not the market price.

The difference price that occurs, in the implementation of execution of the debtor's collateral object, the creditor should pay attention on the debtor's right, ie the debtor should get a normal price on the guaranteed good which is being executed. It is related to the debtor's obligation, in case that the object's price is under the value of the debt. It is related to the debtor's obligation that if the selling value of the collateral object is smaller than the value of the debt, the debtor is obliged to repay the debt by selling the other assets.

\section{Research Methods}

This research is kind of normative juridical research, it is research that is focused on examining the application of norms or norms in positive law ${ }^{7}$. Normative Juridical is an approach that uses positivist legit conception. This concept sees law as identical to written norms created and enacted by authorized institutions or authorities. This conception sees law as a normative system that is independent, closed and independent of real life society. ${ }^{8}$ According to Peter Mahmud Marzuki that normative legal research is "a process of finding a rule of law, legal principles, and legal doctrines to address the legal issues

\footnotetext{
${ }^{5}$ Abdul R. Saliman 2005 Hukum Bisnis Untuk Perusahaan: Teori dan Contoh Kasus Fifth Edition Kencana Jakarta p. 14-15.

${ }^{6}$ Rachmadi Usman 2016 Hukum Jaminan Keperdataan First Edition Sinar Grafika Jakarta p. 38.

${ }^{7}$ Johnny Ibrahim 2006 Teori dan Metodologi Penelitian Hukum Normatif Bayumedia Publishing Malang p. 295.

${ }^{8}$ Ronny Hanitijo Soemitro 1990 Metodologi Penelitian Hukum dan Jurimetri Ghalia Indonesia Jakarta p.13-14.
} 
faced"9.

Referring to the expert opinion above, the method of problem approach used in this research research is: The statute approach, used to conduct tracing, inventory and study of the legislation of positive law as well as related legal instruments with the law of material security. The conceptual approach is an approach that moves from the views and doctrines that develop in the science of law. Doctrine or view is used to see the legal doctrine of the scholars. Case approach is an approach done by doing the tracking along with legal analysis to various law of material assurance conducted by creditors to debtor whose guarantee brought by market price.

Normative legal research has always focused on secondary data sources. Secondary data on the research can be distinguished into primary legal materials, where the primary legal Material, namely legal materials or decisions or legislation binding and related to the law of material security under the market price between. Secondary law materials provide an explanation of primary legal materials, such as research materials and scientific papers and scholarly opinions that can be obtained from textbooks and journals that are of relevance to the study as well as tertiary legal materials that provide guidance as well as explanations of primary and secondary legal materials, such as Big Indonesian Dictionary, English dictionary, computer and internet term dictionaries and legal dictionaries.

\section{Result And Discussion}

\subsection{The Process of Selling Guaranteed Immovable Objects under Indonesian Positive Law}

Based on Article 6 of Act No. 4/1996 on the Land and Property Rights related to Land (hereinafter referred to as the HT Law), the holder of the Mortgage Right (hereinafter referred to as MR) has the right to sell the MR object on its own power through a public auction, it is used to repay the creditors' receivables. ${ }^{10}$ The right to sell MR objects on their own powers is one embodiment of the preferred position that MR holders possess. The right is based on the promise given by the MR giver that if the debtor breaches the pledge, MR holder is entitled to sell the object through a public tender without requiring any further approval from the MR holder and subsequently to take out the receivable from the proceeds of the sale prior to the other creditor. The remainder of the sale remains the rights of the MR giver. ${ }^{11}$

Implementation of public auction must be done at Auction Hall. Auction Hall itself is an Indonesian legal entity in the form of Limited Liability Company specially established to conduct business activities in the field of auction ${ }^{12}$. Under the aforementioned rules, the Auction Hall is not only the State Property Office and the Auction (hereinafter referred to as KPKNL), but also other Auction Centers registered and obtained the permission of the Director General of State Assets (hereinafter referred to as the Director General) on behalf of the Minister of Finance of the Republic of Indonesia. Auction Centers may be established by ${ }^{13}$ : Private national: Private national joint venture with foreign private; or Joint Venture BUMN/D with national/foreign private institution.

Application for operational license of Auction Hall to Director General must be completed

\footnotetext{
${ }^{9}$ Hidayatullah, Gunarto, Anis Mashdurohatun and Ahmad Rofiq, "Ideal Reconstruction of Law Number 41 Year 2004 on the Position and the Authority of Money Wakaf Law Based on Justice Values Towards Improving the Moslem Economyc", in International Journal of Economic Research, Volume 14 Number 152017 p. 317

${ }^{10}$ Article 6 Act No. 4 of 1996 On Agraria (Land and Hypotec Right)

11 Ibid.

12 Article 1 No. 1 Economical Ministry of Indonesia No. 176/PMK.06/2010 On "Balai Lelang".

13 Ibid. Article 2
} 
with requirements document, among others: ${ }^{14}$ Deed of establishment of Auction Hall made in front of Notary and authorized by authorized institution; Proof of paid up capital of at least Rp2,500,000,000 (two billion five hundred million rupiahs); Newspaper's account on behalf of the respective Auctioneer, Proposal for establishment of Auction Hall, Certificate or proof of ownership or lease agreement, etc.

The initial procedure in selling of immovable goods is an auction request. The auction request shall be conducted by the seller, in this case the creditor, by submitting a letter of auction request along with the auction requirements document to KPKNL to request the schedule of auction implementation. In the event that the auction requirements document has been completed and the formal legality of the subject and auction object has been fulfilled, and the owner of the goods-in this case the creditor on the basis of the mortgage certificate available to him-has authorized the Auction to sell by auction, an auction request to the Head of KPKNL or Class II Auction Official to be asked for the auction schedule.

If there is a lawsuit prior to the auction of MR objects from any party other than the debtor, husband or wife of debtors related to ownership, the auction of execution of Article 6 of the HT Act cannot be implemented. The implementation of the auction contain dispute, the aforementioned will be done based on the executorial title of the mortgage certificate requiring the fiat of execution.

The seller or the auctioneer is responsible for the validity of the ownership of the goods; the validity of the tender requirements document; transfer of movable and/or immovable goods; transfer of ownership documents to buyers; and the determination of the limit value. Seller is responsible for any civil lawsuits and/or criminal charges arising from noncompliance with the rules of the auction by the seller. The seller is also liable for claims for damages for damages incurred, in the case of not fulfilling the responsibilities mentioned above.

\subsection{Measures that Debtors Can Do If the Immovable Guaranteed Objects are sold by Creditor below the Market Price}

First of all it needs to be understood in advance regarding the pricing of purchases in the auction process and the role of market prices in the auction process. In banking practice, the principle that the value of the asset must be greater than the amount of debt, this ratio is regulated in Bank Indonesia Regulation no. 18/16 / PBI / 2016 on Loan to Value Ratios for Property Loans, Financing to Value Ratios for Property Financing, and Advances for Credit or Motor Vehicle Financing. For loans with collateral in the form of Dependent Rights in general the value of the Deposit Rights is at least $125 \%$ of the value of the loan. The value of these Insurers' Rights should be stated in the Mortgage Benefit Document.

At the time of the auction, a limit of every auction is required. The limit value is the minimum price of the goods to be auctioned and fixed by the Seller. The determination of the value of the limit shall be the responsibility of the seller determined on the basis of the assessor's assessment by the assessor. An appraiser is an independent value maker based on his/her competence, whereas the assessor is an internal party of a salesperson conducting an assessment based on methods that can be accounted for by the seller, including curators for art and antiquities or antiquities.

In practice, the lawsuit of auction cancellation due to an assessment of the value of a limit below the market price adverse to the debtor is often the case and is conducted on the basis of the Against the Law under Article 1365 of the Civil Code which provides that any

${ }^{14}$ Ibid. Article 4 line (2) 
act which violates the law and brings harm to others, obliges the person who causes the loss for his mistake to compensate for the loss. Based on that article, it can be seen that an act against the law if it qualifies or elements: there must be an act against the law, there must be a mistake, there must be a cause and effect relationship between deeds and losses; and there must be a loss.

In relation to the element of error, it is necessary to know in relation to the reasons justifying an act and the reasons that exclude the element of error. In first, the act of unlawful disappearance is against the law, for example by force, emergency, statutory provisions and orders the authority. As for knowing what reasons can negate the element of error, then the error should be associated with the elements below: ${ }^{15}$

- Mistakes in relation to deed do not exist in psychics defect condition;

- Errors in relation to the unlawful nature of the act are not present, in the absence of a psychics defect, noodweer exces, an official order given by an unauthorized person;

- The error in relation to loss does not exist, if a person has realized that he has committed an act against the law, but the losses incurred by his actions are not to be expected.

\subsection{Legal Protection for Debtor in Selling the Immovable Guarantee Objects Based on Indonesian Positive Law Provisions}

Subekti specifies that the engagement or covenant is a legal relationship (between property and wealth) between two or more persons, which entitles one to demand something other than the other, while the other is required to fulfill the demand ${ }^{16}$. Debt agreements are basically a form of agreement bound by the basic theories of the agreement. As a condition of the validity of debt agreements, it must comply with Article 1320 of the Civil Code which includes: Agree to bind themselves; The ability to make an agreement; A certain thing; and A lawful cause.

The form of the warranty agreement in practice is in written form. This cannot be separated from the procedures in loading the guarantee on an object. All mortgage, fiduciary, pledge and mortgage rights require warranty agreements which are written in the process of loading them. This is related to one of the principles of the guarantee institution, namely the existence of the principle of publicity. This principle prioritizes the importance of publications to the general public regarding whether an object has been burdened with a guarantee or not.

Legal protection for debtors in selling of immovable collateral objects below the market price can be divided into sections namely: Debtor position related to the determination of the limit value; The position of the debtor in the event of auction cancellation; The position of the debtor in the case of the sale of a security object under the hand; and the position of the debtor when the item has been sold and is in a third party.

Based on regulations issued by the Minister of Finance, the determination of the limit value is determined by the seller. In the case of the auction of the execution of collateral under Article 6 of the Mortgage Right Law, there is no provision that the creditor should sit with the debtor discussing the agreement with respect to the limit value. The condition is determined only that the determination of the value of the limit is done by the interpreter or assessor with a method that can be accountable. In this section, it is possible creditors make a mistake that if for the guarantee of more than a billion rupiah the determination of the limit is only done by the internal interpreter and not an independent appraiser.

\footnotetext{
${ }^{15}$ Achmad Busro 2012 Hukum Perikatan Berdasar Buku III KUH Perdata Revision Edition Pohon Cahaya Semarang p. 116.

${ }^{16}$ Subekti 2003 Pokok-Pokok Hukum Perdata Intermasa Jakarta p. 122.
} 


\section{CLOSING}

\subsection{Conclution}

- The sale of immovable objects may be done in two ways through auction of execution under Article 6 of the Mortgage Right Law, and underhand selling. If the selling is through the auction, then no agreement is required first from the debtor. The creditor as the holder of the mortgage can directly conduct the auction process in accordance with the provisions of legislation, while if the sale is under the hand, it is required for prior agreement of the debtor;

- In relation to the actions that a debtor may perform on the sale of a guaranteed item at a below-market price, if the sale is made through an auction, a loss of a lawsuit against the law may be required only if there is a faulty procedure in the auction process. Meanwhile, if the sale is done under the hands of the sale value below the market price, what can be done by the debtor is in the form of a lawsuit against the law. The difference between the two is related to the percentage of debtor's victory in the judicial process; and

- Viewed from the four aspects discussed, the legal protection of the debtor has not been given properly. These aspects include: Debtor position related to the determination of the limit value, the position of the debtor in the event of cancellation of the auction, the position of the debtor in the case of the sale of the under-handed security object; and the position of the debtor when the item has been sold and is in a third party.

\subsection{Suggestion}

Based on the conclusions as mentioned above, the authors provide suggestions such as:

- It shall also be stipulated in the placement of underhand collateral objects, which may have a positive impact on the value of the collateral;

- should be regulated in legislation so as to achieve benefits for the parties; and

- Need to be re-regulated in relation to legal protection for debtors in selling the collateral objects in the form of immovable goods below the market price. So the debtor gets the rights attached to it.

\section{References}

[1] Achmad Busro 2012 Hukum Perikatan Berdasar Buku III KUH Perdata Revision Edition Pohon Cahaya Semarang.

[2] Article 6 Act No. 4 of 1996 On Agraria (Land and Hypotec Right)

[3] Bryan A. Garner ed 2009 Black's Law Dictionary Ninth Edition West St. Paul.

[4] Rachmadi Usman 2016 Hukum Jaminan Keperdataan First Edition Sinar Grafika Jakarta.

[5] Ronny Hanitijo Soemitro 1990 Metodologi Penelitian Hukum dan Jurimetri Ghalia Indonesia Jakarta.

[6] Abdul R. Saliman 2005 Hukum Bisnis Untuk Perusahaan: Teori dan Contoh Kasus Fifth Edition Kencana Jakarta.

[7] Johnny Ibrahim 2006 Teori dan Metodologi Penelitian Hukum Normatif Bayumedia Publishing Malang.

[8] Subekti 2003 Pokok-Pokok Hukum Perdata Intermasa Jakarta.

[9] Hidayatullah, Gunarto, Anis Mashdurohatun and Ahmad Rofiq, "Ideal Reconstruction of Law Number 41 Year 2004 on the Position and the Authority of Money Wakaf Law Based on Justice Values Towards Improving the Moslem Economyc', in International 
Volume 5 Issue 2, June 2018

Journal of Economic Research, Volume 14 Number 152017

[10] Article 1 No. 1 Economical Ministry of Indonesia No. 176/PMK.06/2010 On "Balai Lelang". 